
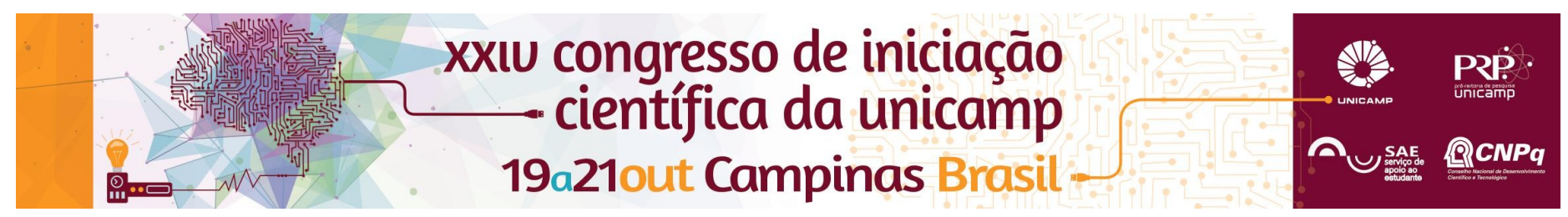

\title{
ÍTALO CALVINO E OS CLÁSSICOS: OVÍDIO NAS SEIS PROPOSTAS PARA O PRÓXIMO MILÊNIO
}

\author{
Thiago Lopes Araújo*, Isabella Tardin Cardoso
}

\begin{abstract}
Resumo
Esta pesquisa pretende observar mais de perto a presença de Ovídio, o autor de Roma antiga, em Six Memos for the Next Millenium de Italo Calvino. Adotando metodologia intertextual (Conte 1996; Vasconcellos 2007; Cardoso 2009), analisaremos algumas traduções de excertos selecionados e discorreremos sobre algumas de suas características poéticas, visando entender de que maneira tais obras da Antiguidade citadas por Calvino apresentam elementos estilísticos que permitem o autor apontá-las como paradigma para as qualidades que defende como compatíveis com a literatura do atual milênio.
\end{abstract}

\section{Palavras-chave:}

Letras Clássicas, Ovídio, Italo Calvino

\section{Introdução}

Em 1985, Ítalo Calvino é convidado a ministrar palestras no contexto das Charles Eliot Norton Poetry Lectures, na Universidade de Harvard (EUA). Nascem, então, as ("Seis propostas para o Próximo Milênio"). As seis propostas tratam de valores literários a serem conservados no futuro. Ali, a referência mais ampla a Ovídio se dá sobretudo no capítulo que trata da leveza ("lightness") no estilo. Mas, surpreendentemente, o tema do episódio citado não é necessariamente leve: são versos da obra Metamorfoses em que se narra o mito de Medusa (o célebre monstro com cabeças de serpente, que transformava em pedra quem o encarasse). Ovídio mesmo chega a caracterizar o monstro como "plúmbeo" (Met. IV 706-710). Perguntamonos, portanto, que características poéticas dos respectivos versos das Metamorfoses permitem a Calvino apontar tal narrativa ovidiana como exemplo de leveza. Na exposição, as referências ao texto latino seguem Barchiesi e Rosati (2004) e as traduções da obra de Ovídio aqui citadas são de Carvalho (2010).

\section{Resultados e Discussão}

No poema ovidiano, a leveza está em Perseu,que, fugindo para as nuvens ("quando, súbito, o herói, os pés premendo a terra, se eleva até as nuvens"; Met. IV, 711-712), se eleva, e vence ao fazer a adversária olhar sua própria imagem refletida no espelho, transformando-se em pedra. Depois disso, impressiona Calvino o cuidado do herói, que deposita a cabeça do monstro, sem feri-la (ne laedat, Met. IV, 741): Perseu "amolece" (mollit, Met. IV, 742) a dura areia (dura harena, Met. IV, 741) ao forrá-la com folhas e plantas "nascidas sob o mar" (sub aequore natas, Met. IV, 742). A partir daí, verifica-se o surgimento dos corais (dotados de rigidez, mas não estéreis (Met. IV,747-749); além disso, do sangue derramado pela decapitação da
Medusa, nasce Pégaso (Met. IV, 784-785) o cavalo que, por ter asas, é fugaz. A leveza apreciada por Calvino nessa narrativa da derrota de Medusa por Perseu é, portanto, o resultado não necessariamente de um tema, por si, leve, mas da forma resultante de aspectos característicos do modo de operar ovidiano, como e.g. "a contraposição de elementos díspares e o equilíbrio entre elementos contrários" (Carvalho, 2010, p. 21). Tais elementos são favorecidos pela presença de associações múltiplas que estruturam a narrativa das Metamorfoses do poeta romano.

\section{Conclusão}

Conclui-se que a recepção de Ovídio nas Seis Propostas de Italo Calvino representa a leitura que este faz dos Clássicos: a partir de uma perspectiva contemporânea sobre a literatura, o autor italiano procura manter valores estilísticos que, para ele, seriam imprescindíveis à literatura do século XXI.

\section{Agradecimentos}

Agradecemos à Universidade Estadual de Campinas e ao PIBIC/CNPq, pela bolsa de iniciação científica concedida para a realização deste projeto.

\section{CALVINO, I. (1988).Six Memos for the Next Millennium. Cambridge.} (1990) Seis Propostas para o Próximo Milênio: Lições Americanas. Trad. I. Barroso. São Paulo. . $(2002)^{14}$. Lezioni Americane: Sei Proposte per il Prossimo Millennio. Milano.

CARDOSO, I. T. (2009) “Theatrum mundi: Philologie und Illusion" in J. P. Schwindt (ed.), Was ist eine Philologische Frage? Frankfurt, pp. 82-111. CARVALHO, R. B. (2010). Metamorfoses em tradução. USP. São Paulo. CONTE, G. B. (1996). Letteratura latina. Firenze

OVIDIO. (2004). Metamorfosi. A cura di A. Barchiesi e G. Rosati. Trad. L. Koch. Roma.

VASCONCELLOS, P. S. (2007) Reflexões sobre a noção de "arte alusiva" e de intertextualidade no estudo da poesia latina. Classica 20.2, pp.239-260. 